\title{
Preliminary screening on wound healing potential of Ocimum tenuiflorum I. using in vitro assays
}

\author{
${ }^{1}$ Rohini, J., ${ }^{2}$ Mansoureh, N.V., ${ }^{2}$ Fouad Saleih, R.Al-S.,,${ }^{*}$ Rabeta, M.S. and \\ ${ }^{2}$ Amin Malik Shah, A.M. \\ ${ }^{1}$ Food Technology Division, School of Industrial Technology, Universiti Sains Malaysia, 11800 Penang. \\ ${ }^{2}$ EMAN Testing and Research Laboratories, Department of Pharmacology, School of Pharmaceutical \\ Sciences, Universiti Sains Malaysia, 11800 Penang.
}

\begin{abstract}
Article history:
Received: 17 January 2019

Received in revised form: 18 January 2019

Accepted: 19 January 2019

Available Online: 24 January 2019
\end{abstract}

Keywords:

Ocimum tenuiflorum,

Wound healing,

Cell proliferation,

Cell migration,

Angiogenesis

DOI:

https://doi.org/10.26656/fr.2017.3(3).010

\begin{abstract}
Herbal plants were used for food flavouring and food preservation and for the treatment of some illnesses. Ocimum tenuiflorum was one of the ancient herbal plants whereby its medicinal properties have been widely studied such as wound healing. Wound healing involves a sequence of recovery stages and many factors affect the wound healing process. The literature review showed that, leaves part was widely studied by researchers for its wound healing potential. The aim of this study was to screen the wound healing potential of other parts of the plants which are the stems and flowers in comparison to leaves using in vitro wound healing assays. Aqueous extraction for all the parts was done using the maceration method. The stems and flowers extracts did not show any promising wound healing effects through cell migration and angiogenesis process but showed significantly $(p<0.05)$ higher effect via cell proliferation activity. Conversely, leaves extract have shown positive wound healing potency by significantly enhanced $(p<0.05)$ the cell migration and angiogenesis activity. Overall, this experiment proved that the leaves own wound healing potency via cell migration and angiogenesis activity which could be beneficial in wound healing process. Thus, O. tenuiflorum leaves extract can be a favorable wound healing treatment yet, further detailed studies are required.
\end{abstract}

\section{Introduction}

Medicinal plants have been extensively investigated in the development of nutraceutical and herbal supplements because they are rich in bioactive compounds and essential oils (Amit et al., 2013). These plants have been used as traditional medicines to treat many illnesses and health problems (Chowdhury et al., 2017). The demand for these plants likely increases because they have less side effect compared to commercially used pharmaceutical drugs (Palla et al., 2012).

Among various types of medicinal plants, Ocimum tenuiflorum, an ancient plant, has been used traditionally to treat numerous illnesses (Pattanayak et al., 2010). This plant is known as the "Queen of Herbs" because it can produce a considerable amount of essential oils consisting of numerous aromatic compounds (Upadhyay et al., 2015). Commonly called as tulsi or holy basil, this plant belongs to the family of Lamiaceae (Cohen, 2014). Jain et al. (2015) indicated that almost all parts, including leaves, stems, flowers, roots, and fruits, of this plant, have medicinal properties. Previous scientific studies confirmed the plant's medicinal properties, such as antioxidation (Rabeta and Lai, 2013), antidiabetes (Mousavi et al., 2016), anticancer (Lam et al., 2018), hepatoprotection (Lahon and Das, 2011), antiinflammation (Kumar et al., 2015) and wound healing properties (Francis et al., 2017).

Wound healing is a tissue recovery process that occurs after injuries ensue (Khamlue et al., 2012). This process is complex because of its overlapped phases involving bleeding, inflammatory, proliferative, and remodeling phases (Mohamed Amin et al., 2015). Complete tissue recovery and skin function restoration are important factors in wound healing to regain skin integrity (Sasidharan et al., 2011).

Animal-based products may conflict with religious of wound patients' beliefs (Eriksson et al., 2013). Researchers and manufacturers should consider the potential of plant-based wound healing product can benefit these patient groups. Therefore, this study was conducted to determine the wound healing potential of 
different parts of $O$. tenuiflorum using in vitro assays.

\section{Materials and methods}

\subsection{Plant material collection and extraction}

$O$. tenuiflorum plants were collected from the botanical garden, Perak. The plant was identified and authenticated by Dr. Rahmad Zakaria at School of Biological Sciences, Universiti Sains Malaysia (USM) (Herbarium number is 11400).

The collected plant materials were separated accordingly to their parts (leaves, stems, and flowers) and were weighed to obtain the initial weight and washed with running tap water. The washed materials were oven dried at $60^{\circ} \mathrm{C}$ for $24 \mathrm{hrs}$. Then the weight of the dried sample was recorded, and the materials were ground to fine powder mesh 60 . The weight of the powdered material was recorded and stored in dark and air-tight container.

Sample (leaves, stem and flowers) extractions were done separately. The extraction steps were based on the effectiveness in wound healing study by Shetty et al. (2008) with some modification. Approximately $10 \mathrm{~g}$ of sample was mixed with $100 \mathrm{~mL}$ of distilled water in a conical flask. The mixture was then shaken in an orbital shaker at $160 \mathrm{rpm}$ at $27^{\circ} \mathrm{C}$ for $24 \mathrm{hrs}$ followed by centrifugation at $3500 \mathrm{rpm}$ for $30 \mathrm{mins}$ to obtain the clear extract. The supernatant was transferred to a beaker and evaporated using the oven at $60^{\circ} \mathrm{C}$ until semisolid extract was obtained. The obtained extract was stored in an airtight container until use.

\subsection{Cell culture maintenance}

A human endothelial cell line, EA.hy926 cells (ATCC, Manassas, VA, U.S.A.), were grown in flask containing Dulbecco's modified Eagle's medium (DMEM) premixed with 10\% fetal bovine serum (FBS), growth supplements, antibiotics consist of L-glutamine, and $1 \%$ penicillin-streptomycin. The flask was then incubated in $5 \% \mathrm{CO}_{2}$ at $37^{\circ} \mathrm{C}$. Cells at $80-90 \%$ confluence were used for seeding and treatment for the experiment (Dao et al., 2016).

\subsection{Cell proliferation assay}

The cells were seeded into each well of a 96-well plate in triplicate at a density of $5 \times 10^{5}$ in $100 \mu \mathrm{L}$ medium per well. The plate was then incubated for $24 \mathrm{hrs}$ at $37^{\circ} \mathrm{C}$ in $5 \% \quad \mathrm{CO}_{2}$. The medium was premixed with concentrations of $12.5 \mathrm{ug} / \mathrm{mL}$ and $200 \mathrm{ug} / \mathrm{mL}$ of extracts treatment and incubated for $72 \mathrm{hrs}$. Then, the cell morphology images were taken using microscope followed by a $10 \mu \mathrm{L}$ of $5 \mathrm{mg} / \mathrm{ml}$ of $3-(4,5-$ Dimethylthiazol-2-yl)-2, 5-diphenyl Tetrazolium
Bromide (MTT) reagent was added to each well and then incubated for 3-4 hrs. Finally, the medium was discarded, and the purple formazan formed was dissolved by adding $150 \mu \mathrm{L}$ of dimethyl sulfoxide (DMSO) to all the wells including control (without treatment). The plate was gently swirled to mix well and incubated for 30 mins in dark area at room temperature. The cells proliferations were observed using TECON microplate reader at $570 \mathrm{~nm}$ with reference of $620 \mathrm{~nm}$. Graph of absorbance against the number of cells was plotted to determine the cells proliferation as per standard methods (Muhammad et al., 2013).

\subsection{Cell migration assay}

The cells were seeded into each well of a 6-well plate in triplicate and incubated at $37^{\circ} \mathrm{C}$ in $5 \% \mathrm{CO}_{2}$ until a confluent cell monolayer. Next, the media was pipetted out and discarded followed by, a small area was scratched using sterile $200 \mu \mathrm{L}$ pipette tip, and the cells were then rinsed with phosphate buffer solutions (PBS) to remove the loosened debris of the cells. Two concentrations of extracts dissolved in media $(12.5 \mu \mathrm{g} /$ $\mathrm{mL}$ and $200 \mu \mathrm{g} / \mathrm{mL}$ ) were added to the wells and the plate was incubated at $37^{\circ} \mathrm{C}$ in $5 \% \mathrm{CO}_{2}$. The distance between two layers of the scratched cells was inspected and captured using a digital camera attached to microscope and computer system at $0,6,12$, and until the treatment wells cells closed. The distance of cells migration was analyzed using ImageJ software (Muhammad et al., 2013).

\subsection{Rat aorta ring assay}

\subsubsection{Animal preparation}

Three adult male Sprague-Dawley (SD) rats weighing around 200-230 g, age 8-10 weeks old were used in this experiment. All the rats were kept under 12 hrs light and dark cycle and allowed for free access to food and water. The experiment was carried out in accordance with Universiti Sains Malaysia (USM) animal ethics committee guidelines and approval. The ethical approval number is USM/IACUC/2018/ (111) (915).

\subsubsection{Preparation of assay media}

Two parts of media were prepared according to Aisha et al. (2012). Part A media consists of $3 \mathrm{mg} / \mathrm{mL}$ of fibrinogen, $5 \mu \mathrm{g} / \mathrm{mL}$ of aprotinin and $1 \%$ L-glutamine dissolved in M199 serum-free growth media while Part B media consists of $20 \% \mathrm{FBS}, 1 \% \mathrm{~L}$-glutamine, $0.1 \% 6$ aminocaproic acid, $1 \%$ amphotericin and $0.6 \%$ gentamicin dissolved in M199 serum-free growth media. Thrombin was separately prepared at concentration 50 NIH U/I. 
2.5.3 Isolation, seeding and treatments of rat aorta rings

The assay was done according to the method described by Samad et al. (2018) with slight modifications. Firstly, the rat was anesthetized using ketamine and xylazine intraperitoneally $40-100 \mathrm{mg} / \mathrm{kg}$ and $5-13 \mathrm{mg} / \mathrm{kg} \mathrm{BW}$, respectively. Then, a rat dissection was done to excise the aorta and the fibro-adipose tissue was carefully removed. The aorta was then rinsed and flushed with freshly prepared and filtered media. About $1 \mathrm{~mm}$ thickness, the aorta was sliced and seeded into each well of a 48 -well plate (Coster Corning, USA) containing $500 \mu \mathrm{L}$ of the part A media. The rings were adjusted to the center of each well and solidify using 10 $\mu \mathrm{L}$ of thrombin. The plate was incubated at $37^{\circ} \mathrm{C}$ under $5 \% \mathrm{CO}_{2}$ for at least $3 \mathrm{hrs}$. Then, the part B media which was premixed with the plant extracts with concentrations of 12.5 and $200 \mu \mathrm{g} / \mathrm{mL}$, respectively was added to each well in triplicates. DMSO was used as a negative control. On the 4th day, the top layer of media was discarded and replaced with freshly prepared part B media premixed with the extract and incubated again. On day 5th, the sprouting blood vessels formed from aortic rings were observed and captured using a digital camera attached to microscope and computer system and data were analyzed using ImageJ software.

\subsection{Statistical analysis}

Data were expressed as mean \pm standard error mean (SEM). Results were analyzed statistically using oneway ANOVA followed by Tukey post hoc test and $\mathrm{p}<0.05$ is considered statistically significant.

\section{Results}

\subsection{Cell proliferation assay}

Figure 1 shows the cell proliferation effect of the EA.hy926 cell was significantly higher $(p<0.05)$ in stems

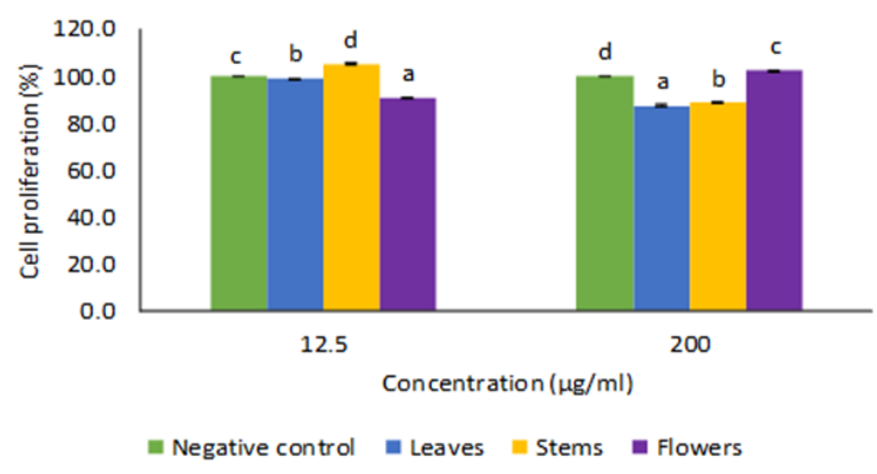

Figure 1. Cell proliferation effect of EA.hy926 cell when treated with 12.5 and $200 \mu \mathrm{g} / \mathrm{ml}$ concentration of different parts of $O$. tenuiflorum plant extracts. *Value represented as mean \pm SEM $(n=3)$ and different alphabets were considered statistically significant when $(\mathrm{p}<0.05)$ and flowers extracts at the concentrations of $12.5 \mu \mathrm{g} / \mathrm{mL}$ and $200 \mu \mathrm{g} / \mathrm{mL}$, respectively when compared to negative control. Figure 2 shows that the proliferation effect of EA.hy926 cells after treated with different parts of $O$. tenuiflorum extracts. It can be seen that the number of cells was higher in $12.5 \mu \mathrm{g} / \mathrm{mL}$ treated stem extract when compared to the negative control group.

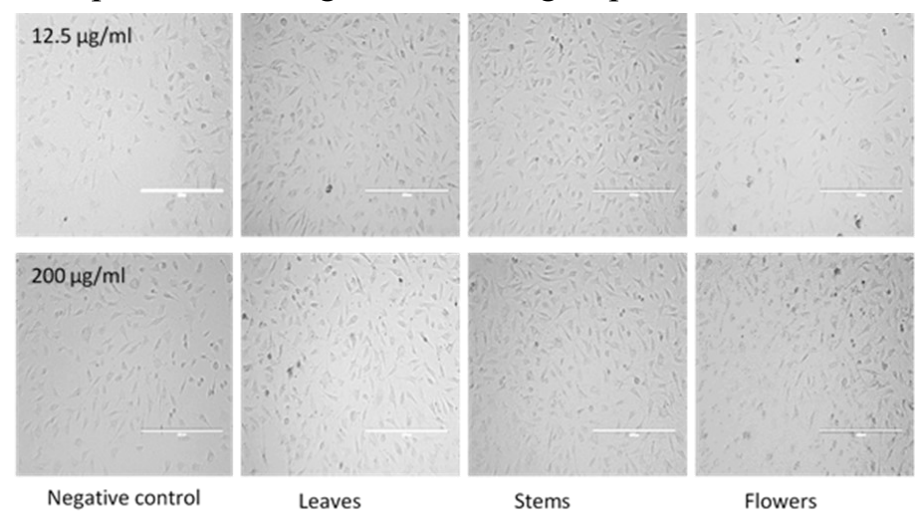

Figure 2. Microscopic view of EA.hy926 cells when treated with different parts of $O$. tenuiflorum extracts

\subsection{Cell migration assay}

Figure 3 shows the cell migration effect of the EA.hy926 cell was significantly $(\mathrm{p}<0.05)$ enhanced up to $90 \%$ in leaves extract treated group at the concentration of $12.5 \mu \mathrm{g} / \mathrm{mL}$ within $12 \mathrm{hrs}$ when compared to negative control group. Figure 4a that the leaves extract of $O$. tenuiflorum treated cells migrated and closes the scratch area almost $100 \%$ within $12 \mathrm{hrs}$ at $12.5 \mu \mathrm{g} / \mathrm{mL}$ concentration when compared to negative control and other treatment groups. Figure $4 \mathrm{~b}$ shows that the leaves extract of $O$. tenuiflorum treated cell migrated and closes the scratch area faster than stem and flower extracts treated group. The cell migrated faster in leaves extract and closes the wound about $90 \%$ when compared to negative control group within $12 \mathrm{hrs}$ when treated at 200 $\mu \mathrm{g} / \mathrm{mL}$ of concentration.

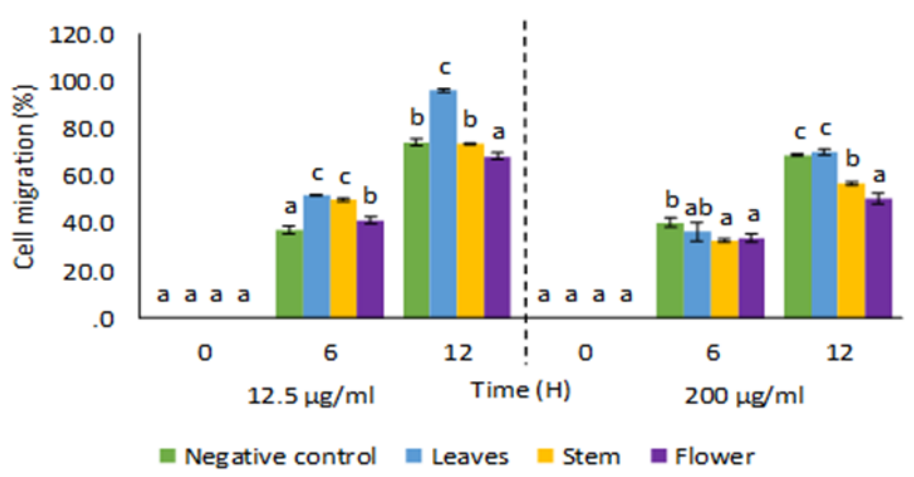

Figure 3. Cell migration effect of EA.hy926 cell when treated with 12.5 and $200 \mu \mathrm{g} / \mathrm{ml}$ concentration of different parts of $O$. tenuiflorum plant extract. *Value represented as mean \pm SEM $(n=3)$ and different alphabets were considered statistically significant when $(\mathrm{p}<0.05)$ 


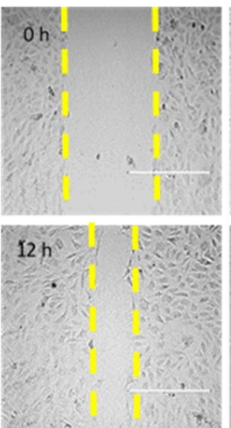

Negative control

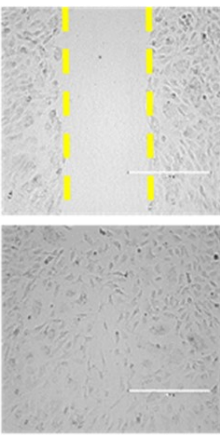

Leaves

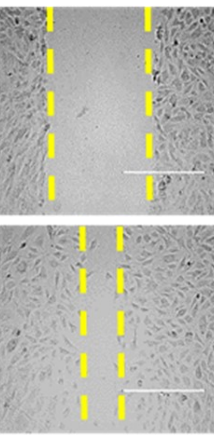

Stems

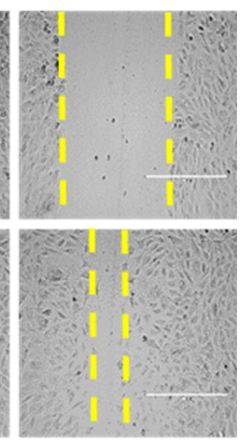

Flowers

Figure 4a. Microscopic view of cell migration when treated with $12.5 \mu \mathrm{g} / \mathrm{ml}$ of different part of $O$. tenuiflorum extracts

\subsection{Rat aorta ring assay}

Figure 5 shows the proangiogenic effect of the rat aorta ring was significantly increased $(p<0.05)$ when treated with leaves extract at the concentration of 12.5 $\mu \mathrm{g} / \mathrm{mL}$. Figure 6 a shows that the growth of blood vessels (angiogenesis) on day 5 was enhanced in $O$. tenuiflorum leaves extract treated group when compared to negative control and other treatment groups at the concentration of $12.5 \mu \mathrm{g} / \mathrm{mL}$. Figure $6 \mathrm{~b}$ showed that the growth of blood vessels (angiogenesis) was reduced when compared to negative control group on day 5 after treated with $200 \mu \mathrm{g} / \mathrm{mL}$ of different parts $O$. tenuiflorum extracts.

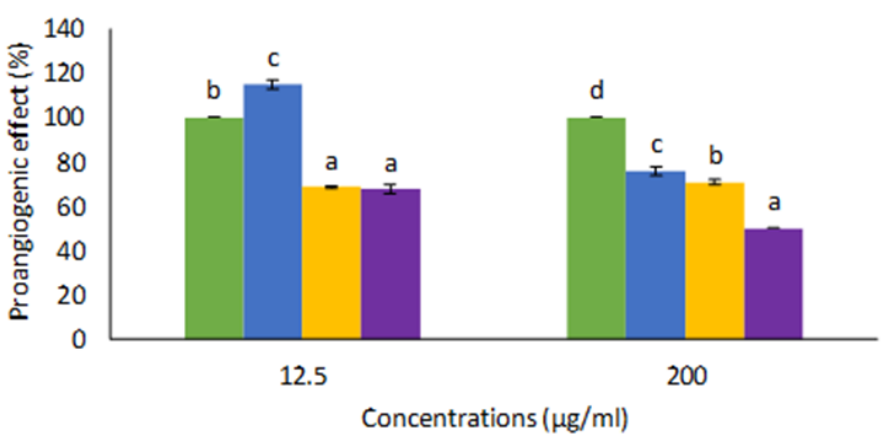

negative control = Leaves

Figure 5. Proangiogenic effect of rat aorta ring when treated with 12.5 and $200 \mu \mathrm{g} / \mathrm{ml}$ concentration of different parts of O. tenuiflorum plant extracts. $*$ Value represented as mean \pm SD $(n=3)$ and different alphabets were considered statistically significant when $(\mathrm{p}<0.05)$

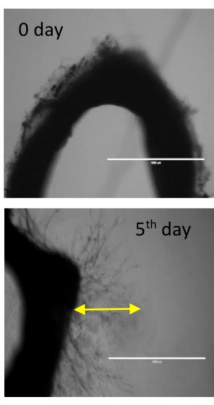

Negative control

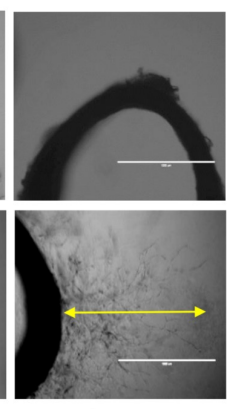

Leaves

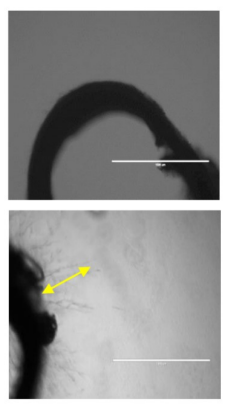

Stems
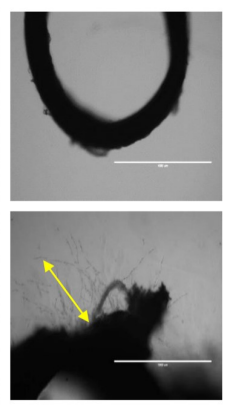

Flowers
Figure 6a. Microscopic view of proangiogenic effect of rat aorta when treated with different parts of $O$. tenuiflorum extracts at concentration $12.5 \mu \mathrm{g} / \mathrm{ml}$

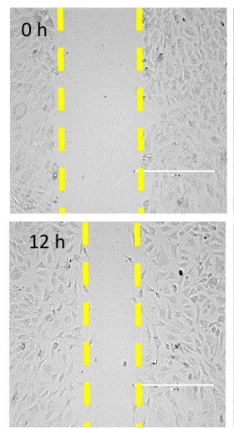

Negative control

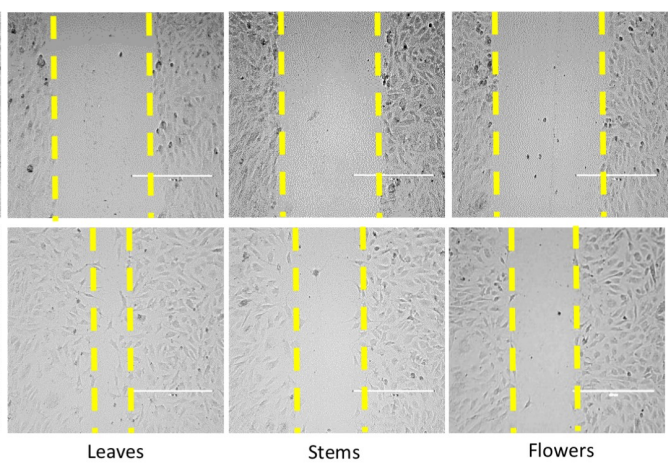

Figure 4b. Microscopic view of cell migration when treated with $200 \mu \mathrm{g} / \mathrm{ml}$ of different part of $O$. tenuiflorum extracts

\section{Discussion}

Wound healing is a natural process of tissue or skin upon injury. It consists of four stages which are the bleeding, inflammation, proliferation, and remodelling stages (Lakshmi et al., 2011). When the skin is cut or injured, bleeding may occur. Once the skin bleeds, the inflammatory phase subsequently starts. In this phase, blood vessels become constricted, leading to the release of inflammatory factors. In the proliferative phase, granulation tissue forms, and this process involves fibroblasts and angiogenesis. In the remodeling phase or the final part of wound healing, a collagen fiber is reformulated and improved, thereby enhancing the tensile strength of the wound (Panda et al., 2011). Given that wound healing comprises different phases, other important factors, such as cell proliferation, cell migration, and angiogenesis, should be considered (Landén et al., 2016). Shah et al. ( 2012) stated that cell proliferation and migration are necessary during wound epithelialization, which is the last part of the proliferative phase. For efficient wound healing, sufficient oxygen and nutrients should be transported regularly. This mechanism happens with the help of blood vessels; oftentimes, pre-existing blood vessels tend to rupture due to injuries, and angiogenesis or the formation of new blood vessels is needed to ease wound healing (Lali and Metcalfe, 2014).

Extracts from different parts of O. tenuiflorum were subjected to three different in vitro assays. Their wound healing potential was evaluated on the basis of their cell

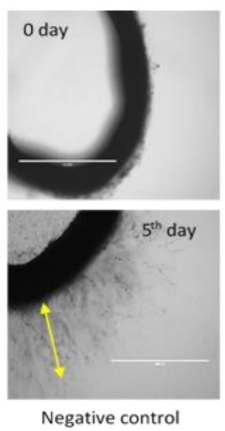

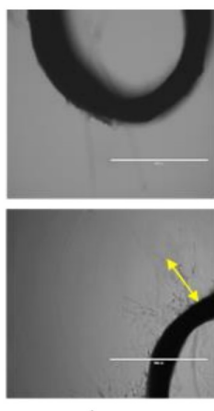

Leaves

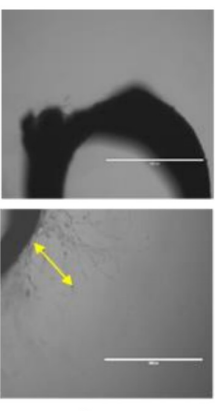

Stems

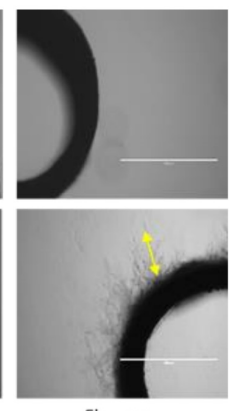

Flowers
Figure 6b. Microscopic view of proangiogenic effect of rat aorta when treated with different parts of $O$. tenuiflorum extracts at concentration $200 \mu \mathrm{g} / \mathrm{ml}$

C 2019 The Authors. Published by Rynnye Lyan Resources 
proliferation, cell migration, and proangiogenic effects. Two of these assays focused on cell migration and angiogenesis and demonstrated that the leaf extract showed a prominent wound healing potential. This finding explained why most literature surveys have shown that leaves are the most commonly studied part of O. tenuiflorum (Goel et al., 2010; Gautam and Goel, 2013; Francis et al., 2017).

A previous study done by Asha et al. (2011), indicated that the potential wound healing properties of $O$. tenuiflorum aqueous leaf extract were probably due to the presence of bioactive compounds such as flavonoids, which act as an antioxidant by scavenging free radicals. Considering that the delay of wound healing is associated with many factors, such as nutrition, diabetes, infections, and aging, oxidative stress is believed to be one of them. Oxidative stress causes cell damage, which impedes wound epithelialization and interrupts the process (Tümen et al., 2018).

Among various nutrients, carbohydrates and proteins are the most needed in this process. Carbohydrate, which is the main source of energy production, produces cellular adenosine triphosphate that aids in wound healing through angiogenesis and inhibits the depletion of protein molecules (Guo and Dipietro, 2010). This depletion leads to prolonged wound healing by dragging the inflammatory phase; interfering the synthesis of fibroplasia, collagen, and proteoglycan; and preventing wound restoration (Mackay and Miller, 2003). Hence, nutritional composition is another possible reason for the potential wound healing properties of $O$. tenuiflorum leaves, which contain higher amounts of carbohydrates and proteins than stems do (Koche et al., 2011).

\section{Conclusion}

Overall, all parts (leaves, stems, flowers) of $O$. tenuiflorum plant owned potential wound healing properties. However, only the leaves extract showed promising results in two assays which is satisfactory for the study. Future studies are needed to further elucidate the possible mechanism lies behind the potential wound healing properties of the plant.

\section{Conflict of Interest}

The authors declare no conflict of interest.

\section{Acknowledgments}

We would like to thank the Research University Grant 1001/PTEKIND/812176 and Graduate assistant (GA) scheme for the financial support.

\section{References}

Aisha, A.F., Abu-Salah, K.M., Alrokayan, S.A., Ismail, Z., Majid, A. and Shah, A.M. (2012). Evaluation of antiangiogenic and antioxidant properties of Parkia speciosa Hassk extracts. Pakistan Journal of Pharmaceutical Sciences, 25(1), 7-14.

Amit, K., Anu, R., Sandip, C., Ruchi, T., Latheef, S. and Kuldeep, D. (2013). Ocimum sanctum (Tulsi): a miracle herb and boon to medical science-a review. International Journal of Agronomy and Plant Production, 4(7), 1580-1589.

Asha, B., Nagabhushan, A. and Shashikala, G. (2011). Comparative study of wound healing activity of topical and oral Ocimum sanctum Linn in albino rats. Al Ameen Journal of Medical Science, 4(4), 309-314.

Chowdhury, S., Poddar, S.K., Zaheen, S., Noor, F.A., Ahmed, N., Haque, S., Sukul, A., Sunjida, S.B., Mazumder, M.M.U. and Akbar, N. (2017). Phytochemical screening and evaluation of cytotoxic and hypoglycemic properties of Mangifera indica peels. Asian Pacific Journal of Tropical Biomedicine, 7(1), 49-52. https://doi.org/10.1016/ j.apjtb.2016.09.009

Cohen, M.M. (2014). Tulsi-Ocimum sanctum: A herb for all reasons. Journal of Ayurveda and Integrative Medicine, 5(4), 251-259. https:// doi.org/10.4103/0975-9476.146554

Dao, C.V., Islam, M.Z., Sudo, K., Shiraishi, M. and Miyamoto, A. (2016). MARCKS is involved in methylmercury-induced decrease in cell viability and nitric oxide production in EA. hy926 cells. Journal of Veterinary Medical Science, 78(10), 1569-1576. https://doi.org/10.1292/jvms.16-0249

Eriksson, A., Burcharth, J. and Rosenberg, J. (2013). Animal derived products may conflict with religious patients' beliefs. BMC Medical Ethics, 14(1), 48-52. https://doi.org/10.1186/1472-6939-14-48

Francis, N.K., Pawar, H.S., Peter, N., Biswas, G., Majumdar, J., Mitra, A. and Mitra, A. (2017). Evaluation of wound healing and antimicrobial physiognomies of alcoholic extract of Ocimum sanctum (basil) in diabetic rabbit model. International Journal of Herbal Medicine, 5(2), 9197.

Gautam, M.K. and Goel, R.K. (2013). Wound healing effect of Ocimum sanctum leaves extract in diabetic rats. International Journal of Medical, Health, Pharmaceutical and Biomedical Engineering, 7, 279 -282 .

Goel, A., Kumar, S., Singh, D.K. and Bhatia, A.K. (2010). Wound healing potential of Ocimum sanctum Linn. with induction of tumor necrosis factor. Indian 
Journal of Experimental Biology, 48(4), 402-406.

Guo, S. and DiPietro, L.A. (2010). Factors Affecting Wound Healing. Journal of Dental Research, 89(3), 219-229. https://doi.org/10.1177/0022034509359125

Jain, S., Mohan, R. and Rai, R. (2015). Ocimum sanctum as an Herbal Medicine: A Review. International Journal of Maxillofacial Research, 1(1), 3-11.

Khamlue, R., Naksupan, N., Ounaroon, A. and Saelim, N. (2012). Skin wound healing promoting effect of polysaccharides extracts from Tremella fuciformis and Auricularia auricula on the ex-vivo porcine skin wound healing model. $20124^{\text {th }}$ International Conference on Chemical, Biological and Environmental Engineering IPCBEE, Vol. 43, p. 9398. Singapore: IACSIT Press

Koche, D., Imran, S., Shirsat, R. and Bhadange, D. (2011). Comparative Phytochemical and Nutritional Studies of Leaves and Stem of Three Lamiaceae Members. Research Journal of Pharmaceutical, Biological and Chemical Sciences, 2(3), 1-4.

Kumar, A., Agarwal, K., Maurya, A.K., Shanker, K., Bushra, U., Tandon, S. and Bawankule, D.U. (2015). Pharmacological and phytochemical evaluation of Ocimum sanctum root extracts for its antiinflammatory, analgesic and antipyretic activities. Pharmacognosy Magazine, 11(Suppl. 1), S217. https://doi.org/10.4103/0973-1296.157743

Lahon, K. and Das, S. (2011). Hepatoprotective activity of Ocimum sanctum alcoholic leaf extract against paracetamol-induced liver damage in Albino rats. Pharmacognosy Research, 3(1), 13. https:// doi.org/10.4103/0974-8490.79110

Lakshmi, A., Rao, Y., Bhargavi, C. and Seelam, U. (2011). Antidiabetic and Wound Healing Activity of various bark extracts of Polyalthia longifolia. Asian Journal of Pharmaceutical and Clinical Research, 4 (1), 109-113.

Lali, F.V. and Metcalfe, A.D. (2014). The role of angiogenesis in wound healing, scarring and tissue regeneration. The PMFA Journal, 2(1).

Lam, S., Neda, G. and Rabeta, M.S. (2018). The anticancer effect of Ocimum tenuiflorum leaves. Food Research, 2(2), 154-162. https:// doi.org/10.26656/fr.2017.2(2).251

Landén, N.X., Li, D. and Ståhle, M. (2016). Transition from inflammation to proliferation: a critical step during wound healing. Cellular and Molecular Life Sciences, 73(20), 3861-3885. https:// doi.org/10.1007/s00018-016-2268-0

MacKay, D.J. and Miller, A.L. (2003). Nutritional support for wound healing. Alternative medicine review, 8 (4), 359-377.
Mohamed Amin, Z., Koh, S.P., Yeap, S.K., Abdul Hamid, N.S., Tan, C.P. and Long, K. (2015). Efficacy study of broken rice maltodextrin in vitro wound healing assay. BioMed Research International, 2015, 687694. https:// doi.org/10.1155/2015/687694

Mousavi, L., Rabeta, M.S., Vikneswaran, M. and Mohd Zaini, A. (2016). Hypoglycemic and antihyperglycemic study of Ocimum tenuiflorum L. leaves extract in normal and streptozotocin-induced diabetic rats. Asian Pacific Journal of Tropical Biomedicine, 6(12), 1029-1036. https:// doi.org/10.1016/j.apjtb.2016.10.002

Muhammad, A.A., Pauzi, N.A.S., Arulselvan, P., Abas, F. and Fakurazi, S. (2013). In vitro wound healing potential and identification of bioactive compounds from Moringa oleifera Lam. BioMed Research International, 2013, 974580. https:// doi.org/10.1155/2013/974580

Palla, R., Elumalai, A., Eswaraiah, M.C. and Raju, K. (2012). A review on Krishna tulsi, Ocimum tenuiflorum Linn. International Journal of Research in Ayurveda and Pharmacy, 3(2), 291-293.

Panda, V., Sonkamble, M. and Patil, S. (2011). Wound healing activity of Ipomoea batatas tubers (sweet potato). Functional Foods in Health and Disease, 1 (10), 403-415. https://doi.org/10.31989/ ffhd.v1i10.118

Pattanayak, P., Behera, P., Das, D. and Panda, S.K. (2010). Ocimum sanctum Linn. A reservoir plant for therapeutic applications: An overview. Pharmacognosy Reviews, 4(7), 95-105. https:// doi.org/10.4103/0973-7847.65323

Rabeta, M.S. and Lai, S.Y. (2013). Effects of drying, fermented and unfermented tea of Ocimum tenuiflorum Linn. on the antioxidant capacity. International Food Research Journal, 20(4), 16011608.

Samad, N.A., Abdul, A.B., Rahman, H.S., Rasedee, A., Ibrahim, T.A.T. and Keon, Y.S. (2018). Zerumbone suppresses angiogenesis in HepG2 cells through inhibition of matrix Metalloproteinase-9, vascular endothelial growth factor, and vascular endothelial growth factor receptor expressions. Pharmacognosy Magazine, 13 (Suppl. 4), S731.

Sasidharan, S., Logeswaran, S. and Latha, L.Y. (2011). Wound healing activity of Elaeis guineensis leaf extract ointment. International Journal of Molecular Sciences, 13(1), 336-347. https://doi.org/10.3390/ ijms 13010336

Shah, J.M.Y., Omar, E., Pai, D.R. and Sood, S. (2012). Cellular events and biomarkers of wound healing. 
Indian Journal of Plastic Surgery: Official Publication of the Association of Plastic Surgeons of India, 45(2), 220. https://doi.org/10.4103/09700358.101282

Shetty, S., Udupa, S. and Udupa, L. (2008). Evaluation of antioxidant and wound healing effects of alcoholic and aqueous extract of Ocimum sanctum Linn in rats. Evidence-Based Complementary an Alternative Medicine, 5(1), 95-101. https://doi.org/10.1093/ ecam/nem004

Tümen, İ., Akkol, E.K., Taştan, H., Süntar, I. and Kurtca, M. (2018). Research on the antioxidant, wound healing, and anti-inflammatory activities and the phytochemical composition of maritime pine (Pinus pinaster Ait). Journal of Ethnopharmacology, 211, 235-246. https://doi.org/10.1016/j.jep.2017.09.009

Upadhyay, A.K., Chacko, A.R., Gandhimathi, A., Ghosh, P., Harini, K., Joseph, A.P., Joshi, A.G., Karpe, S.D., Kaushik, S. and Kuravadi, N. (2015). Genome sequencing of herb Tulsi (Ocimum tenuiflorum) unravels key genes behind its strong medicinal properties. BMC Plant Biology, 15(1), 212 -231. https://doi.org/10.1186/s12870-015-0562-x 